NGTT Deel 54, Nommers $3 \& 4$, September en Desember 2013

Landman, Christina ${ }^{1}$

University of South Africa

\title{
Talking hope - Dirkie Smit and public theology
}

\begin{abstract}
Dirkie Smit creating dialogical space between Habermas' criticism of rationality and the criticism of experience required by the South African context of poverty and gender bias is explored. The contribution of Smit's public voice is argued in terms of a criticism of survival which is as yet unsuccessfully lodged from the "private" spaces of the geographically marginalised, that is, believers living in rural "townships" who do not have access to public spheres or theology. It is concluded that Smit's contextualisation of Habermas' call for a critical rationality in the public sphere finds a legitimate place in him "talking hope", albeit rationally limited, to people who are still oppressed by illiteracy and genderised behaviour. It is proposed that Smit expands the criticism of rationality which he holds in common with Habermas, to a prophetic and public voice that is based on a criticism of experience and survival in which the voices and needs of the voiceless will be heard and contra-cultured.
\end{abstract}

\section{INTRODUCTION}

Known for his preference to use the work of German authors as inter-texts for formulating theories of theology, Dirkie Smit points to the work of Jürgen Habermas as a possible way of defining the "public" in public theology. He does this in an essay, What Does "Public" Mean? Questions with a View to Public Theology (Smit 2007:11-46), which became seminal in defining public theology in the South African context.

The aim of the present essay is to communicate (rather than to argue) on Smit's preferential option for the ideal public sphere as described by Habermas, as well as on Smit's theologisation of this concept. It will be communicated that criticism in the public sphere based on rationality, as proposed by Habermas, needs to accommodate locally a criticism based on experience and survival that reflects the reality of South African communities.

The present essay, then, communicates this "argument" in five phases. First, Habermas' criticism of rationality will be communicated by means of Smit's interpretation thereof. Second, a criticism of experience will be described as alternative to rationality by means of the "private" experiences of a local South African, Piet Sibande. Third, a criticism of survival will be communicated as a second alternative by means of the "public" experiences of a rural South African congregation. Fourth, the possibility that South African churches, at present, publicly pronounce themselves within a criticism of irrationality that, of course, forces us to take another look at Smit and Habermas' plea for rationality in the public sphere.

Lastly, Smit's voice in the public sphere as one of "talking hope" rather than one of "talking rationally" will be discussed as a conclusion to the essay.

1 Christina Landman is Professor of Theology in the Research Institute for Theology and Religion at the University of South Africa.She specialises in gender and oral history. 
NGTT: Oopbron - http://ngtt.journals.ac.za

\section{A CRITICISM OF RATIONALITY: THE CASE OF JÜRgEN HABERMAS}

Smit (2007:11-37) commends Habermas for identifying the public sphere as a prominent feature ofmodern societies, and fordescribing the means to influence this sphere publicly viaa criticism of rationality. Reacting against a public that is sacrificing criticism for consumerism, Habermas promotes a critical public opinion that is based on rational conversation and argumentation (Smit 2007:16). However, engaging in rational communication is not to play mind games, but to engage rationally in furthering basic human conditions such as freedom, humaneness and human dignity. Communicating these values of critical democracy in the public sphere asks for rational communication that is understandable, truthful, and honest in motive.

Smit (2007:32-37) both appreciates and criticises Habermas' views on a criticism of rationality. Smit's criticism revolves around rationality as the only means of mediating transformation. Surely there can also be structural and systemic intervention to open up society towards freedom and human dignity, Smit argues with others (2007:32). On the other hand, Smit's appreciation for Habermas' thinking lies in the possibilities it creates for public theology as a critical - that is, prophetic - voice against state and economic policies that infringe on the freedom and dignity of people.

As Smit himself points out (2007:37), Habermas has changed his initial resistance to religion as per se irrational, to the church as a potentially important role player in conscientisation and transformation. Dreyer and Pieterse (2010) wrote an insightful article in this regard called Religion in the Public Sphere: What can Public Theology Learn from Habermas' Latest Work. They refer to the problematic role religion plays in the public sphere and the contribution Habermas has made in recent years to point to the church's public role both in grounding morality and in giving voice to the marginalised and vulnerable in a post secular society (Dreyer and Pieterse 2010:4).

Although Smit then credits Habermas for indirectly - and of late directly - widening the public sphere to include (secular) forms of public theology, it is precisely here that we need to challenge Habermas on his narrow view of religion as morality and his accommodation of religion in a post secular society with religion having relevance only when it speaks in a (post) secular tongue.

Is Habermas relevant when public theology enters community life in South Africa and how does Dirkie Smit himself challenge Habermas and his criticism of rationality? For this challenge, we shall look at the story of Piet Sibande.

\section{A critisism of experience: the "private" case of Piet Sibande}

Piet Sibande is 55 years old. He is an elder in a Reformed church. His father was an evangelist in the same congregation and two of Piet's brothers are pastors. His grandfather had two wives. Piet has six grown children. Two years ago his wife passed away due to tuberculosis. He now lives in a house with four walls and a tap. He is self-employed. Piet is proudly and culturally Zulu.

Last year Piet paid lobola (bride's prize) for Rosina. She is in her thirties but lobola has never been paid for her. She has children of her own. She is an elder in the same church as Piet. 
NGTT Deel 54, Nommers $3 \& 4$, September en Desember 2013

Piet and Rosina lived together without being legally married, as their church requires. Things soon became violent between them. Piet believes that a married woman should come home immediately after work and start cooking and washing for her husband. Rosina likes to visit her family and to dress up for the shebeen (local tavern). A counsellor at work told her that she does not have to put up with Piet's controlling behaviour. One day when Piet came home, Rosina had left with everything, the bed and the food included. Piet then went to the house of Rosina's mother where she was then staying. He beat Rosina badly and broke the doors of the house when she tried to lock herself in. She managed to call the police and eventually obtained a restraining order against Piet.

The church council met to decide how to act on this issue - Piet was, after all, an elder. However, Piet convinced them that they should act against Rosina. She did not behave like a good wife, left him and was visiting the shebeen even more than before.

Piet now rules the congregation. There is no fulltime minister in the congregation and Piet insists that people should call him mfundisi (pastor). He has gathered a strong church council around him, and he pays pastoral calls on members of the church at their homes. The church is also growing rapidly.

In the above section we have said that Habermas' position - here called a "criticism of rationality" - as applied to the church as public space, empowers the church to be, first, a place where morality is enhanced; second, a platform from where to prophetically criticise the marginalisation of the vulnerable and poor; and third, a place where rationality can be expressed in secular language amongst believers.

What, then, is the public role that the church needs to play in Piet's private life that has bearing on the public life of the church? Piet's context differs radically from that of Habermas. The former lives in a society where he is not free to be moral in terms of the criticism of power that Habermas suggests. Furthermore, Piet's view of the world is premodern, in conflict with the human rights tradition of the younger people around him and his world is not secular, let alone post secular. He lives in a world where culture and religion blend in perfect harmony with male concepts of honour and shame.

Does Dirkie Smit "talkhope"to this context? Or does he, as public theologian, continuously cling to the binary opposition between the privileged oppressors and the vulnerable oppressed, without criticising the power discourses in vulnerable societies? Publicly Smit mainly speaks to a white privileged society because of the historical need for transformation amongst those addressed. However, in the process he, like Habermas, opens up space for public theology to address personal responsibility towards the common good of society where everybody shall have equal access to human dignity - as Smit (1994) does in the essay Morality and Individual Responsibility, to name but one of many.

Smit (2007:32) acknowledges that criticism based on rationality alone is inadequate in bringing about transformation, and that this can and should be done by other means such as spirituality, worship, art - and even exposure to alternative experiences (as he reflects on, for instance, the Truth and Reconciliation Commission - cf. Smit 1995). Therefore, Smit expands a criticism of rationality with a criticism of experience.

When Piet, after his break-up with Rosina, discovered that he was HIV positive, this experience changed his view on the church's participation in HIV counselling - something he previously 
NGTT: Oopbron - http://ngtt.journals.ac.za

explicitly denied being part of the task of the church. The calling of a woman pastor as tentmaker to the congregation may also change Piet's view on regulating his relationships with women by means of male power only. Exposure to experience is leading Piet to stop rationalising uncritically about the onslaughts on male power and to start publicly critiquing existing structural and cultural powers in favour of the humanisation of relationships.

\section{A CRITICISM OF SURVIVAL: THE "PUBLIC" CASE OF SAKHELWE}

The township of Sakhelwe lies high in the hills of Mpumalanga and is for most of the year covered in mist and drenched by rain. Here a congregation in the Reformed tradition exists amongst several African Independent Churches. The people are unemployed and poor. According to the local clinic - a small room in a dilapidated building - the prevalence of HIV infection in the township is $47.2 \%$, almost half of the community. Housing is a serious problem, with up to thirty people and three generations living in a "four room", as the four roomed houses built during the apartheid era are called.

Last year, the young people of this township participated in the countrywide service delivery uprisings to secure better housing for the disadvantaged. During the uprising many of them were shot by the police with rubber bullets and badly wounded. The pastor decided to visit the wounded without thereby displaying a specific political preference, adhering to the biblical command of visiting the sick and incarcerated. However, the church council was wary to join the pastor, since some of the elders were members of the police force that were ordered to shoot at the youngsters.

The reigning political party also invited all the church leaders in the township to attend a meeting. At this meeting they were requested to preach to their congregants not to participate in the service delivery uprisings, and to organise an interdenominational prayer meeting for the whole of the community to pray for peace. Churches - all of which do not have church buildings - would benefit in terms of buildings and property.

For this author, who was representing the Uniting Reformed Church in Southern Africa at the said meeting, the question arose as to the public role of the church in relations to (party) politics and the critical voice of the church's public theology vis-à-vis political structures. From the side of this church, then, it was said that we encouraged a culture of nonviolence amongst our members and would fight for liquor free Sakhelwe - since it was claimed that the youngsters who marched were under the influence. The church would not abandon its critical stance towards the non delivery of services and would not move from this position by being co-opted into development programmes that threatened the prophetic voice of the church. The church would work towards the development of all the people in Sakhelwe, not through party politics, but through non profitable projects that acknowledge both the dignity and the critical voice of the people.

Habermas, of course, could not have foreseen that his ideas would result in the church functioning as a public sphere for criticising political structures or the replacement of his "criticism of rationality" with a "criticism of survival". A criticism of survival leads people to keep their critical stance amidst heavy daily demands for survival. However, this is not a rational stance. It is not a stand taken with the mind and the pen only, but a point of departure where people dirty their hands to work towards transformation. Dirkie Smit will call this the fight for justice. In his article Reformed Ethics and Economic Justice (2007a:379-398), Smit 
NGTT Deel 54, Nommers $3 \& 4$, September en Desember 2013

encourages Christians not to be beneficiaries of justice only, not to see and judge only, but also to act towards realising justice.

Smit's quest for justice is, of course, prominently evident from his writings on and his participation in the formulation of the Belhar Confession (1986). Appropriately, the by now well-known words of Belhar ring out:

We believe that the church should therefore stand by people in any form of suffering and need, which implies amongst things, that the church must witness against and strive against any form of injustice, so that justice may roll down like waters, and righteousness like an ever flowing stream; that the church as the possession of God must stand where he stands, namely against injustice and with the wronged; that in following Christ the church must witness against all the powerful and privileged who selfishly seek their own interests and control and harm others.

Smit himself commented on these words in an essay, On Learning to See? A Reformed Perspective on the Church and the Poor. This essay was based on a paper delivered at the International Academy of Practical Theology in 2001 (2009:473-492). According to Smit, only in seeing the plight of the poor - that is, in experiencing and not in rationalising - do Christians become the public hands for working towards justice.

But has Smit gone far enough? Has he opened up the public sphere for public theology and the church today, in a post apartheid era, for critiquing political, economic and social powers and injustice? To this we turn in the next section.

\section{A CRITICISM OF IRRATIONALITY: the EMBARASSing CASE OF SOUth African CHURCHES}

It was said above that three characteristics of religion, which includes the church, as a forum for public theology and for criticising power structures, stand out. These characteristics have been described rationally with the help of Jürgen Habermas and contextually via Dirkie Smit. First, religion and the church enter the public sphere as morality, but also as the dirtying of hands for both justice and development. Second, religion and the church see the need in post secular society, express themselves prophetically in secular language, and act on the premodern world view of its members. Third, although religion and the church cooperate with public institutions to work towards justice and development, they keep a critical distance visà-vis oppressive power structures. They do so not only base on a "criticism of rationality", but also on a "criticism of experience and survival".

Do South African churches today live up to these ideals? If not, does Dirkie Smit as public theologian address their silence and/or their irrationality?

One can detect three tendencies in the (un)public behaviour of churches in post-apartheid South African society. First, mainline churches in South Africa lose about 5\% of their members annually to charismatic churches. Charismatic churches in South Africa are known both for their no dogmatic and non-political stance. White people who previously were privileged under the apartheid regime tend to move to charismatic churches where they do not have to feel guilty about the past and are not constantly reminded to confess political atrocities. Furthermore, apart from being non-political, these churches are also fundamentalist in the 
NGTT: Oopbron - http://ngtt.journals.ac.za

way they deal with the Bible as well as in the way they deal with society. Their public voice surfaces only in cases of societal fundamentalism, namely when abortions, homosexuality, gender equality and the like are addressed by legislation.

Second, there are indigenous churches that invite political figures and movements into their worshipping midst, adhering to a world view that integrate politics and religion. The piety that supports this view is similar to that which has informed liberation theologies of the 1980s and 1990s and which brought about democratic change in South Africa. Of course, these churches take a noncritical stance vis-à-vis the political power structures that initially were brought about by liberative action.

Third, silence is currently a primary characteristic of denominations and interdenominational organisations that previously criticised the apartheid regime. Since 1994 and the coming of democracy, religious leaders have been appointed in government positions and church organisations that existed because of their criticism of apartheid have weakened and have lost their voices. The South African Council of Churches is one example that comes to mind.

The churches in South Africa that still have a public voice either make social fundamentalist sounds or consenting noises - both of which are irrational in Habermas' terminology. For Habermas and Smit, then, these churches, because of irrationality and fundamentalism, should not have a public voice at all.

The next question is: What is Smit doing at present to guide religion and the churches in South Africa towards a rational voice, albeit based on experience and survival? This is a subtopic in the next section.

\section{Talking hope: the case of Dirkie Smit}

In their discussion of Habermas, Dreyer and Pieterse point to the latter's concept of communicative rationality that is to be distinguished from instrumental rationality: "Rationality is not only a faculty of the mind, positioned in a subject, but something that can be traced in acts of communication" (2010:2). Smit obviously finds himself at home in this definition of rationality as communicative action, and describes in numerous articles its contextualisation in South Africa.

If this author finds Smit's approach to public theology too rational and too thinly contextualised with regard to experience and survival, it is not without appreciation for way in which he - albeit rationally - "talks hope" to the South African audience. His public theologising can in fact be designated here under the heading of "Talking as Hope", that is, rationalising aimed towards the hearts of people. With most of Smit's work directed at an academic and/or privileged audience (finding the latter irrational in their uncritical acceptance of racism), his public theologising nevertheless "talks hope" to South Africans across a broad spectrum in at least three ways:

First, Smit places the work of South African theologians in the public sphere to communicate rationality and think critically. In a recent article, Morality and Politics - Secular or Sacred? Calvinist Traditions and Resources in Conflict in Recent South African Experiences (2009a:513-546), Smit points to denominational and interdenominational organisations that remain silent where a critical and prophetic voice against abuse of political and economic power is needed. In this regard he refers to relevant theologians who are arguing on human 
NGTT Deel 54, Nommers 3 \& 4, September en Desember 2013

dignity in the public sphere. John de Gruchy talks hope on reconciliation and the restoration of justice and places the struggle for human rights, freedom, dignity, justice and peace, and sustainable environmental policies in the public sphere on behalf of Christian humanism for critical discussion with secular humanists. Nico Koopman talks hope when placing morality in the public sphere for a critical discussion between Christians and government policies in a pluralistic democratic society. Piet Naudé talks hope when he opens "cultural justice" up for public debate in a South Africa caught between homogenisation and globalisation. Tinyiko Maluleke talks hope when he invites the South African public (including the churches), to risk critically arguing for moral leadership in the public sphere. Allan Boesak talks hope when he argues for a common life for South Africans without violence and exclusion.To answer the question put at the end of the previous section: Yes, Smit does guide the South African public towards critically and rationally arguing for appropriate values in a new South Africa; and in doing that he does talk hope.

Second, Smit talks hope in calling the interpretation of the Belhar Confession an "on-going task" in his foreword to Piet Naudé's book, Neither Calendar nor Clock: Perspectives on the Belhar Confession (2010). The phrase "on-going task" is used by Naudé himself and internalised by Smit to open up the future, albeit indirectly, for public theology. However, this author regrets that Smit rationalises on this on-going task without concretising it into action.

Third, Smit continuously talks hope in his sermons. It is through his sermons that he speaks to the public in words that do not change with governments. He talks hope when he preaches on the experience of God's power through faith (Eph. 1:20-23). He talks hope when he advises Christians to stand for the truth and to resist oppression (1 Cor. 7:29-31). He talks hope when he encourages the religious public to establish a new basis for social justice (Lk. 15:11-32). He talks hope when he speaks out against partiality and discrimination (James 2:1-13). He talks hope when he dreams with his fellow believers about a new heaven and a new earth where transformation towards a just society will take place (Rev. 21:18) and he talks hope when he preaches about reconciliation and tolerance as the main public values of a new South Africa (Acts 2:8-12).

\section{CONCLUSION}

Dirkie Smit uses Jürgen Habermas' ideal of a public sphere where criticism of power structures is rationally communicated as a basis for defining public theology locally. Although criticising Habermas for mediating criticism mainly through rationality, Smit's own approach to public theology is based on reason rather than experience.

In this essay the experiences of Piet Sibande and a congregation in Sakhelwe were described to relate in three ways the role of the church in being critical towards present political, economic and social injustices. When the church becomes not only a moral leader, but dirties its hands with development and the quest for justice, when the church speaks prophetically in premodernist societies governed by secular powers, and when the church speaks from the experience of people, a "criticism of rationality" as proposed by Habermas and Smit, is expanded into a "criticism of experience and survival".

Smit's contribution to public theology, then, lies in his critique of the irrationality of racism and other forms of oppression. In a post-apartheid society he talks hope, albeit rationally limited, to people whose lives are still governed by authoritarianism, indignity, gender stylisation, underdevelopment and poverty. 
NGTT: Oopbron - http://ngtt.journals.ac.za

Perhaps Smit's greatest contribution lies in the inter-texts he uses to talk hope. Through him the thinking of European (especially German) philosophers and theologians, and those of local liberation and humanist theologians, has become public property. Through them, his thinking has become part of the common good of the people.

\section{BiBLIOGRAPHY}

Dreyer, J. S. and Pieterse, H. J. C. 2010. Religion in the Public Sphere: What can Public Theology Learn from Habermas' Latest Work? HTS Teologiese Studies/Theological Studies 66(1), 17.

Naudé, P. 2010. Neither Calendar nor Clock: Perspectives on the Belhar Confession. Grand Rapids, Ml: Eerdmans.

Smit, D. J. 1988, 1988a, 1989, 1990, 1992, 1994a. Exegesis and Proclamation. Journal of Theology for Southern Africa 63, 65, 66, 71, 81, 86, 59-67, 73-79, 62-73,59-68, 55-56, 81-87. Smit, D. J. 1994. Morality and Individual Responsibility. Journal of Theology for Southern Africa 89 (Dec.), 1930.

Smit, D. J. 1995. The Truth and Reconciliation Commission - Tentative Religious and Theological perspectives. Journal of Theology for Southern Africa 90 (March), 315.

Smit, D. J. 2007. What Does "Public" Mean? Questions with a View to Public Theology. In Hansen, L.D. (ed.), Christian in Public. Aims, Methodologies and Issues in Public Theology. Beyers Naudé Centre Series on Public Theology. Stellenbosch: Sun Press, 1146.

Smit, D. J. 2007a. Reformed Ethics and Economic Justice. D. J. Smit, Essays in Public Theology: Collected Essays I. Conradie, E. M. (ed.) Stellenbosch: Sun Press, 379-98.

Smit, D. J. 2008. Wat Beteken "Publiek"? Vrae met die Oog op Publieke Teologie. In Smit, D. J., Geloof en Openbare Lewe. Versamelde Opstelle 2 (Faith and Public Life. Collected Essays 2). Koopman, N. N. (ed.) Stellenbosch: Sun Press, 334.

Smit, D. J. 2009. On Learning to See? A Reformed Perspective on the Church and the Poor. In Smit, D. J., Essays on Being Reformed. Collected Essays 3. Vosloo, R. R. (ed.) Stellenbosch: Sun Press, 473-492.

Smit, D. J. 2009a. Morality and Politics - Secular or Sacred? Calvinist Traditions and Resources in Conflict in Recent South African Experiences". In Essays on Being Reformed. Collected Essays 3, 513-546.

\section{KEY WORDS}

Dirk Smit

Jürgen Habermas

Expanding criticism of rationality - uitbreiding van kritiek van rasionaliteit

Public Theology

Hope

\section{TREFWOORDE}

Dirk Smit

Jürgen Habermas

Uitbreiding van kritiek van rasionaliteit

Publieke Teologie

Hoop

Contact Details/Kontakbesonderhede

Prof Christina Landman

Research Institute for Theology and Religion

Unisa

PO Box 392

Pretoria

0003

E-pos: landmc@unisa ac.za 